\title{
PENERAPAN MODEL PEMBELAJARAN ADVANCE ORGANIZER UNTUK MENINGKATKAN PENGUASAAN KONSEP FISIKA SISWA SMA
}

\author{
Fitri Kusuma Ningrum ${ }^{1}$, Muhammad Nasir ${ }^{2}$, M. Rahmad ${ }^{3}$ \\ 1) Program Studi Pendidikan Fisika FKIP, Universitas Riau, SMA Negeri 1 Rumbio Jaya \\ 2,3) Program Studi Pendidikan Fisika FKIP, Universitas Riau \\ fitridningrum01@gmail.com
}

\begin{abstract}
ABSTRAK: Penelitian ini bertujuan untuk mengetahui peningkatan penguasaan konsep fisika siswa melalui penerapan model advance organizer pada materi momentum dan impuls. Metode penelitian yang digunakan adalah quasy eksperiment dengan desain pretest posttest control group design. Populasi penelitian yaitu seluruh siswa kelas X MIPA SMAN 1 Rumbio Jaya yang merupakan sampel penelitian dengan kelas X MIPA 1 sebagai kelas eksperimen yang berjumlah 23 orang siswa dan kelas X MIPA 2 sebagai kelas kontrol yang berjumlah 24 orang siswa. Instrumen penelitian menggunakan soal tes penguasaan konsep. Data dianalisis secara deskriptif dengan melihat daya serap, efektivitas pembelajaran dan hasil skor penguasaan konsep siswa serta dianalisis secara inferensial menggunakan uji T-test. Hasil analisis deskriptif diperoleh daya serap rata-rata siswa kelas eksperimen sebesar 81,61\% dengan efektivitas pembelajaran berkategori efektif. Selanjutnya untuk penguasaan konsep tiap indikator kelas eksperimen pada indikator pertama dan kedua diperoleh kategori amat baik, pada indikator ketiga diperoleh kategori sedang dan indikator keempat dengan kategori rendah. Hasil analisis inferensial diperoleh peningkatan yang signifkan penguasaan konsep siswa pada kelas yang menerapkan model pembelajaran Advance Organizer terhadap kelas dengan pembelajaran konvensional. Berdasarkan hasil penelitian, maka model pembelajaran advance organizer dapat meningkatkan penguasaan konsep siswa pada materi momentum dan impuls kelas X SMAN 1 Rumbio Jaya.
\end{abstract}

Kata kunci: Advance organizer, fisika, efektivitas, penguasaan konsep. 


\title{
THE APPLICATION OF ADVANCED ORGANIZER LEARNING MODELS TO IMPROVE THE MASTERY OF HIGH SCHOOL PHYSICS CONCEPTS
}

\begin{abstract}
ABSTRCT: This research aimed to determine the improve in mastery of students' physics concepts through the application of an advanced organizer model on material momentum and impulses. The research method used was quasy experiment with pretest posttest control group design. The research population is all students of class X MIPA SMAN 1 Rumbio Jaya which is a sample of research with class X MIPA 1 as an experimental class totaling 23 students and class X MIPA 2 as a control class of 24 students. The research instrument used the concept mastery test questions. Data were analyzed descriptively by looking at absorption, learning effectiveness and the results of students' concept mastery scores and analyzed inferentially using the T-test. Descriptive analysis results obtained an average absorption of experimental class students by $81.61 \%$ with the effectiveness of learning categorized effectively. Furthermore, for the mastery of the concept of each experimental class indicator on the first and second indicators obtained very good categories, the third indicator obtained the medium category and the fourth indicator with a low category. The results of inferential analysis obtained a significant increase in the mastery of student concepts in the class applying the Advance Organizer learning model to the classroom with conventional learning. Based on the results of the research, the advanced organizer learning model can improve students' mastery of the concepts in the material momentum and impulses of class X SMAN 1 Rumbio Jaya.
\end{abstract}

Keywords: Advance organizer, physics, effectiveness, mastery of concepts 


\section{PENDAHULUAN}

Pendidikan merupakan suatu proses pembinaan, pengayoman, pengajaran dan pembentukan karakter manusia atau siswa, baik fisik dan mental untuk mencapai suatu tujuan. Tujuan pendidikan yang harus dicapai pada hakikatnya merupakan bentuk-bentuk atau pola tingkah laku yang harus dikuasai oleh siswa, baik pengetahuan, sikap, maupun keterampilan. Pengetahuan, sikap, maupun keterampilan dapat diperoleh siswa dalam lembaga pendidikan melalui suatu proses pembelajaran (Syaiful Bahri Djamarah, 2002). Terdapat beberapa faktor yang memengaruhi kegiatan proses pembelajaran, diantaranya faktor guru, faktor siswa, sarana, alat dan media yang tersedia, serta faktor lingkungan (Wina Sanjaya, 2008). Peranan guru dalam proses pembelajaran sangat penting. Namun, prestasi dan pemahaman yang dicapai siswa tidak hanya dipengaruhi oleh tingkat pengetahuan guru terhadap materi pembelajaran yang akan diajarkan, tetapi yang juga ikut menentukan adalah model pembelajaran yang digunakan.

Selama ini proses pembelajaran fisika cenderung bersifat teacher centered dengan metode pembelajaran yang cenderung monoton dan kurang melibatkan siswa dalam menemukan suatu konsep dalam proses pembelajaran. Pembelajaran seperti itu menimbulkan ketidaktahuan pada diri siswa mengenai proses maupun sikap dari konsep fisika yang diperoleh. Oleh karena itu, hendaknya dilakukan perubahan paradigma proses pembelajaran. Perubahan paradigma yang dimaksud adalah perubahan dari pembelajaran yang bersifat teacher centered ke pembelajaran yang berorientasi pada student centered (Erlina Sofiani, 2011). Hal ini menekankan siswa untuk terlibat aktif dalam proses pembelajaran sebagaimana siswa yang aktif dalam pembelajaran berbeda pemahamannya dengan siswa kurang aktif.

Berdasarkan hasil wawancara dengan guru fisika SMAN 1 Rumbio Jaya di peroleh bahwa pembelajaran fisika selama ini masih berpusat pada guru melalui pola pengajaran teori-contohlatihan. Pola ini merujuk pada metode ceramah, pemberian contoh, serta pemberian tugas latihan dalam proses pembelajaran. Dapat dilihat pada nilai rata-rata ulangan harian siswa dalam pembelajaran fisika, khususnya pada materi momentum dan impuls selama beberapa tahun pembelajaran sebagian besar penguasaan konsep pada materi tersebut masih kurang. Hal ini ditunjukkan oleh fakta hasil ulangan harian rata-rata siswa yaitu: Tahun $2016=52,12$; Tahun $2017=60,30$; dan Tahun $2018=55,83$. Siswa yang mencapai nilai Kriteria Ketuntasan Minimum 75 yang ditetapkan sekolah hanya $40 \%$ yang tuntas. Diantara penyebabnya, karena kurangnya variasi dan inovasi dalam penyajian materi, siswa hanya diberikan teori-teori dan menghafal rumus-rumus, siswa tidak dibiasakan untuk mengembangkan potensi berpikir mereka sendiri dalam mencari dan menemukan pengetahuannya.

Salah satu upaya untuk meningkat-kan penguasaan siswa tentang konsep-konsep sains dalam kehidupan sehari-hari pada pembelajaran di kelas yaitu saling keterkaitannya materi yang dipelajari dengan pengalaman sehari-hari. Oleh karena itu model pembelajaran yang dapat digunakan yaitu Advance Organizer. Model ini merupakan suatu cara belajar untuk memperoleh pengetahuan baru yang dikaitkan dengan pengetahuan yang telah ada. Model pembelajaran ini bertujuan untuk memperkuat struktur kognitif siswa dan menambah daya ingat 
(retensi) siswa terhadap informasi yang bersifat baru (Miftahul Huda, 2013).

Model pembelajaran Advance Organizer yang dikembangkan oleh Ausubel merupakan penerapan konsepsi tentang struktur kognitif didalam merancang pembelajaran. Penggunaan model pembelajaran Advance Organizer dapat meningkatkan kemampuan siswa dalam mempelajari materi baru dengan ringkasan konsep-konsep dasar tentang apa yang dipelajari dan hubungannya dengan materi yang telah ada dalam struktur kognitif siswa (Asri Budiningsih, 2012). Menurut Miftahul Huda (2013) model pembelajaran Advance Organizer merupakan suatu model pembelajaran yang pada prinsipnya siswa dapat menyerap, mencerna dan mengingat bahan pelajaran dengan baik. Dalam kegiatannya siswa dapat menjelaskan kembali materi tersebut, sehingga mendapat pengalaman belajar yang berbeda dalam mempelajari materi yang baru. Model ini merupakan cara untuk membantu siswa berpikir lebih luas dalam menganalisi konsep serta akan memengaruhi cara belajar siswa yang cenderung pasif ke arah yang lebih aktif (Tasiwan, et al. 2014).

Model pembelajaran Advance Organizer telah diujicobakan oleh Nopriyanto (2010) yang menunjukkan bahwa adanya peningkatan sikap positif siswa dalam pembelajaran matematika. Jahratun Mika et al. (2014) dalam penelitiannya juga telah membuktikan bahwa model pembelajaran Advance Organizer dapat meningkatkan hasil belajar siswa. Selain itu, model pembelajaran Advance Organizer juga telah diteliti oleh Intan Putriana et al. (2017) tentang penerapan model pembelajaran Advance Organizer untuk meningkatkan pemahaman konsep dan keterampilan berpikir kritis siswa pada materi fluida dinamis di SMA Negeri 5 Banda Aceh. Hasil penelitian menunjukkan terjadinya peningkatan pemahaman konsep dan keterampilan berpikir kritis siswa pada pembelajaran fisika.

Menurut Sri Anita et al. (2008) guru menggunakan model pembelajaran Advance Organizer untuk mengaktifkan skemeta siswa (eksitensi pemahaman siswa), agar mengetahui apa yang telah dikenal siswa dan untuk membantu mengenal relevansi pengetahuan yang telah dimiliki. Advance Organizer memperkenalkan pengetahuan baru secara umum yang dapat digunakan siswa sebagai kerangka untuk memahami isi informasi baru secara terperinci.Menurut Aunurrahman (2009) model pembelajaran Advance Organizer terdiri dari tiga tahap yang dapat dilihat pada Tabel 1.

Tabel 1. Sintaks model Advance Organizer

\begin{tabular}{ll}
\hline Tahap & Kegiatan Guru \\
\hline Tahap-1 & $\begin{array}{l}\text { 1. Menjelaskan tujuan pembelajaran } \\
\text { Presentasi }\end{array}$ \\
$\begin{array}{l}\text { 2.Penyajian materi awal } \\
\text { Organce } \\
\text { (penyajian }\end{array}$ & $\begin{array}{l}\text { 3. Menumbuhkan kesadaran pengetahuan dan } \\
\text { pengalaman siswa yang relevan }\end{array}$ \\
materi awal) & \\
\hline $\begin{array}{l}\text { Tahap-2 } \\
\text { Penyajian materi } \\
\text { pembelajaran }\end{array}$ & $\begin{array}{l}\text { 2. Menjelaskan materi pembelajaran } \\
\text { 3. Membangkitkan perhatian siswa }\end{array}$ \\
\hline
\end{tabular}




\begin{tabular}{ll}
\hline Tahap-3 & 1. Meningkatkan keaktifan aktivitas pembelajaran \\
Penguatan & $\begin{array}{l}\text { 2. Mengembangkan pendekatan kritis guna } \\
\text { organisasi }\end{array}$ \\
kognitif & memperjelas materi pembelajaran \\
\hline
\end{tabular}

Bruce Joyce (2009) menyatakan bahwa Advance Organizer berfungsi untuk menjelaskan, mengintegrasikan, dan mengaitkan pengetahuan yang sedang dipelajari dengan pengetahuan yang telah dimiliki oleh siswa. Model pembelajaran ini konsisten dengan pemikiran Ausubel bahwa struktur kognitif yang sudah ada bertindak sebagai alat pengait informasi baru. Sedangkan Ausubel mengemukakan bahwa tujuan Advance Organizer adalah mengaitkan bahan bermakna yang akan dipelajari (pengetahuan baru) dengan struktur kognitif yang dimiliki siswa. Namun perlu digaris bawahi bahwa Advance Organizer bukan merupakan sebuah rangkuman umum materi bahan ajar yang akan dipelajari, tetapi merupakan penyajian singkat informasi visual atau verbal dari materi baru yang akan dipelajari.

Penguasaan konsep menurut Patta Bundu (2006) menyatakan bahwa siswa yang dianggap telah menguasai konsep adalah siswa yang dapat memberikan tanggapan terhadap pertanyaanpertanyaan yang bervariasi pada kelompok atau kategori yang sama. Penguasaan konsep merupakan kemampuan siswa dalam memahami fisika secara ilmiah, baik konsep secara teori maupun penerapannya dalam kehidupan sehari-hari termasuk sikap siwa (Akinyemi, 2015).

Indikator penguasaan konsep yang digunakan sebagai pedoman adalah indikator penguasaan konsep menurut Wirasito yang dikutip dari Putri Wulan Juliana (2015) menyatakan indikator penguasaan konsep yaitu dapat:

a. mengetahui ciri-ciri suatu konsep,

b. menghubungkan antar suatu konsep,

c. kembali pada konsep awal diberbagai situasi,

d. menggunakan konsep dalam menyelesaikan suatu masalah.

\section{METODE}

Metode penelitian yang digunakan adalah Quasi Eksperimen dengan desain Pretest Posttest Control Group Design terhadap dua kelas yaitu kelas eksperimen dan kelas kontrol. Kedua kelas diberi perlakuan yang berbeda, kelas eksperimen diterapkan model pembelajaran Advance Organizer, sedangkan kelas kontrol diajarkan dengan pembelajaran konvensional. Rancangan penelitian menurut skematik berikut:

\begin{tabular}{|llll|}
\hline Eksperimen & $\mathrm{O}_{1}$ & $\mathrm{X}$ & $\mathrm{O}_{2}$ \\
Kontrol & $\mathrm{O}_{3}$ & - & $\mathrm{O}_{4}$ \\
\hline
\end{tabular}
$\mathrm{X}=$ Perlakuan dengan menerapkan model Advance Organizer
$\mathrm{O}_{1}=$ Skor pretest kelas eksperimen
$\mathrm{O}_{2}=$ Skor posttest kelas eksperimen 
$\mathrm{O}_{3}=$ Skor pretest kelas kontrol

$\mathrm{O}_{4}=$ Skor posttest kelas control

Subjek penelitian yaitu siswa kelas X MIPA SMAN 1 Rumbio Jaya tahun ajaran 2018/2019, yang terdiri dari kelas X MIPA 1 sebagai kelas eksperimen yang berjumlah 23 siswa dan kelas X MIPA 2 sebagai kelas kontrol dengan jumlah 24 siswa. Penentuan subjek penelitian ini dilakukan dengan uji normalitas dan uji homogenitas terhadap data sekunder pada ulangan harian materi sebelumnya. Penentuan kelas eksperimen dan kelas kontrol pada dua kelas homogen menggunakan teknik simple random sampling dengan cara undi.

Instrumen penelitian yang digunakan adalah soal tes penguasaan konsep. Teknik pengumpulan data dengan memberikan tes penguasaan konsep pilihan ganda beralasan sebelum dan setelah proses pembelajaran dilaksanakan pada kedua kelas. Teknik analisis data yang digunakan adalah teknik analisis deskriptif dan analisis inferensial.

Analisis deskriptif dilakukan untuk melihat daya serap, efektivitas pembelajaran dan hasil tes penguasaan konsep siswa. Daya serap yang diperoleh siswa digunakan ketentuan:

$$
\text { skor }=\frac{\text { skor yang diperoleh siswa }}{\text { skor maksimum }} \times 100 \%
$$

Pedoman untuk mengetahui daya serap dan efektivitas pembelajaran siswa menurut Tabel 2.

Tabel 2. Kategori daya serap dan efektivitas pembelajaran Depdiknas (2006)

\begin{tabular}{cll}
\hline \multirow{2}{*}{ Interval (\%) } & \multicolumn{2}{c}{ Kategori } \\
\cline { 2 - 3 } & Daya Serap & Efektivitas Pembelajaran \\
\hline $\mathbf{8 5} \leq \mathbf{x} \leq \mathbf{1 0 0}$ & Sangat Baik & Sangat Efektif \\
$\mathbf{7 0} \leq \mathbf{x}<\mathbf{8 5}$ & Baik & Efektif \\
$\mathbf{5 0} \leq \mathbf{x}<\mathbf{7 0}$ & Cukup Baik & Cukup Efektif \\
$\mathbf{0} \leq \mathbf{x}<\mathbf{5 0}$ & Kurang Baik & Kurang Efektif \\
\hline
\end{tabular}

Untuk mengetahui penguasaaan konsep fisika siswa, maka digunakan tes pilihan ganda beralasan sesuai dengan indikator yang berjumlah 12 item. Adapun ketentuan penskoran yang diberikan pada hasil pre-test dan post-test adalah sebagai berikut:

1) Jika jawaban benar dan alasan tepat memperoleh skor 4 ,

2) Jika jawaban benar dan alasan kurang tepat memperoleh skor 3 ,

3) Jika jawaban benar dan alasan salah memperoleh skor 2,

4) Jika jawaban salah alasan salah memperoleh skor 1 ,

5) Tidak menjawab memperoleh skor nol.

Selanjutnya masing-masing skor perolehan tiap indikator pada pre-test dan post-test dianalisis. Untuk menghitung skor masing-masing indikator penguasaan konsep digunakan 
persamaan 1. Pengkategorian penguasaan konsep yang diperoleh siswa dari hasil proses pembelajaran menurut Wayan Nurkancana dan Sunartana (2003) dapat digunakan kriteria sebagaimana Tabel 3.

Tabel 3. Kategori penguasaan konsep siswa

\begin{tabular}{cc}
\hline Interval $(\%)$ & Kategori \\
\hline$X \geq 90$ & Sangat Tinggi \\
$80 \leq X<90$ & Tinggi \\
$64 \leq X<80$ & Sedang \\
$55 \leq X<64$ & Rendah \\
$X<55$ & Sangat Rendah \\
\hline
\end{tabular}

Selanjutnya analisis inferensial dilakukan untuk mengetahui perbedaan peningkatan penguasaan konsep siswa setelah diterapkan model pembelajaran advance organizer pada kelas eksperimen dan pembelajaran konvensional pada kelas kontrol.

\section{HASIL DAN PEMBAHASAN}

Penguasaan konsep siswa pada materi momentum dan impuls dianalisis melalui daya serap, efektifitas pembelajaran, dan penguasaan konsep tiap indikator. Hasil analisis datanya ditunjukkan pada Tabel 4.

Tabel 4. Daya serap kelas eksperimen dan kelas kontrol

\begin{tabular}{ccllll}
\hline $\begin{array}{c}\text { Interval } \\
(\boldsymbol{x})\end{array}$ & Kategori & \multicolumn{2}{c}{$\begin{array}{c}\text { Kelas } \\
\text { Eksperimen }\end{array}$} & Kelas Kontrol \\
\cline { 3 - 6 }$(\boldsymbol{\%})$ & & $\mathrm{N}$ & $\%$ & $\mathrm{~N}$ & $\%$ \\
$\mathbf{8 5} \leq \boldsymbol{x} \leq \mathbf{1 0 0}$ & Amat & 8 & 34,7 & 2 & 8,3 \\
& Baik & & & & \\
$\mathbf{7 0} \leq \boldsymbol{x}<\mathbf{8 5}$ & Baik & 15 & 65,2 & 22 & 91,6 \\
$\mathbf{5 0} \leq \boldsymbol{x}<\mathbf{7 0}$ & Cukup & 0 & 0 & 0 & 0 \\
& Baik & & & & \\
$\mathbf{0} \leq \boldsymbol{x}<\mathbf{5 0}$ & Kurang & 0 & 0 & 0 & 0 \\
\multicolumn{2}{c}{ Rata-rata } & & 81,61 & & 76,82 \\
\hline
\end{tabular}

Berdasarkan Tabel 4 diketahui daya serap kelas eksperimen dari 100\% siswa terdapat $34,7 \%$ siswa yang memiliki daya serap pada kategori amat baik dan 65,2\% siswa yang memiliki daya serap pada kategori baik. Sedangkan daya serap pada kelas kontrol dari $100 \%$ siswa terdapat $8,3 \%$ siswa yang memiliki daya serap dengan kategori amat baik, selanjutnya terdapat 91,6\% siswa yang memiliki daya serap dengan kategori baik. Rata-rata daya serap yang 
diperoleh siswa pada kelas eksperimen yaitu 81,61\% dengan kategori efektif.

Hasil dari posttest yang diberikan menunjukkan skor rata-rata penguasaan konsep yang diperoleh kelas eksperimen adalah $81,61 \%$ dengan kategori tinggi, sedangkan skor rata-rata penguasaan konsep pada kelas kontrol adalah 76,82\% dengan kategori sedang. Dari skor ratarata yang diperoleh diantara kedua kelas terlihat bahwa kelas eksperimen memiliki skor ratarata penguasaan konsep yang lebih tinggi dibandingkan kelas kontrol, hal ini disebabkan karena pada kelas eksperimen menerapkan model pembelajaran advance organizer. Model ini memiliki tiga tahapan diantaranya penyajian materi awal, penyajian materi pembelajaran dan memperkuat pengelolaan struktur kognitif. pada tahap pertama siswa didorong untuk mengingat kembali konsep-konsep yang telah dipelajari sebelumnya yang berkaitan dengan materi yang akan diajarkan. Hal ini akan menarik perhatian siswa serta dapat memudahkan siswa untuk menerima materi pelajaran sehingga dapat memperkuat daya ingat siswa. Dari hasil analisis data penguasaan konsep tiap indikator melalui model pembelajaran advance organizer terlihat pada Gambar 1.

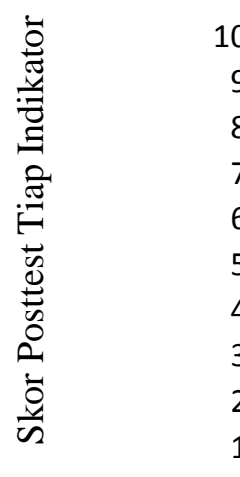

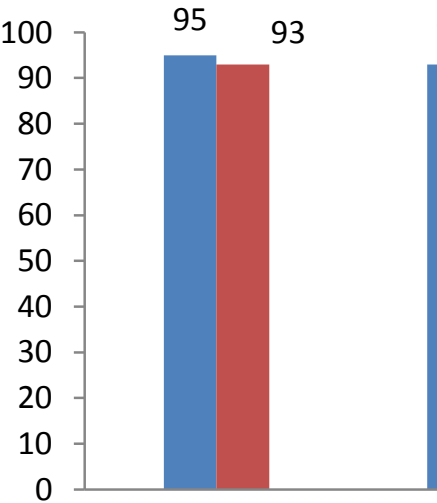

1

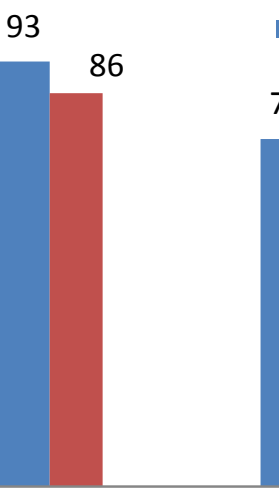

2
Kelas Eksperimen Kelas Kontrol

76

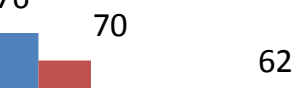

Indikator Penguasaan Konsep

Gambar 1. Grafik hasil skor posttest tiap indikator penguasaan konsep.

Berdasarkan grafik pada Gambar 1 diketahui bahwa tiap indikator penguasaan konsep pada kelas eksperimen secara keseluruhan libik tinggi dibandingkan kelas kontrol. Indikator pertama mengetahui ciri-ciri suatu konsep merupakan kemampuan untuk mengidentifikasi atau menjelaskan suatu konsep berdasarkan peristiwa yang yang telah diberikan. Indikator pertama kelas eksperimen diperoleh rata-rata skor 95 dengan kategori amat tinggi, sedangkan kelas kontrol juga dengan kategori amat tinggi yakni 93. Kedua kelas mendapatkan nilai dengan kategori amat tinggi dikarenakan soal-soal pada indikator pertama tergolong pada soal yang mudah.

Indikator penguasaan konsep kedua yakni dapat menghubungkan antar konsep merupakan kemampuan untuk menghubungkan suatu contoh peristiwa dengan beberapa konsep yang ada. Indikator penguasaan konsep kedua rata-rata skor kelas ekperimen 93 kategori amat tinggi dan pada kelas kontrol skor rata-rata 86 pada kategori tinggi. Melalui model pembelajaran advance 
organizer siswa diminta untuk mengingat materi yang pernah dipelajari dengan materi baru yang akan dipelajari lalu mengaitkan kedua konsep tersebut.

Indikator ketiga dari data yang diperoleh rata-rata skor pada indikator ketiga kelas eksperimen mendapatkan skor 76 dengan kategori sedang dan kelas kontrol skor rata-rata 70 dengan kategori sedang. Faktor perbedaan skor rata-rata ini disebabkan karena model pembelajaran advance organizer yang mengaitkan konsep-konsep yang telah dimiliki dengan materi baru, sehingga siswa dituntut untuk berpikir kritis. Saat mengerjakan soal-soal penguasaan konsep pada indikator ketiga ini siswa pada kelas eksperimen lebih mudah mengerjakannya, karna siswa lebih paham dan mudah mengingat, hal ini sejalan dengan penelitian Ani Susilaningsih (2014) dan penelitian Nurul Hamdanillah et al. (2017). dalam penelitiannya dimana model Advance organizer berpengaruh terhadap hasil belajar siswa.

Indikator keempat yakni menggunakan konsep untuk menyelesaikan suatu masalah merupakan indikator penguasaan konsep dengan tingkatan soal yang tergolong sulit, siswa dituntut untuk menganalisa suatu peristiwa serta dapat menghitungnya. Skor rata-rata kelas eksperimen yaitu 62 sedangkan nilai rata-rata pada kelas kontrol adalah 59. Indikator keempat di kelas ekperimen walaupun tergolong rendah namun lebih tinggi dibanding kelas kontrol sebab siswa diminta untuk memahami konsep baru dengan sendirinya dan mengemukakan pendapatnya dalam berdiskusi dengan teman sekelompoknya.

Hasil analisis inferensial dari output Independent Sample T-Test diperoleh nilai signifikansi (sig.2 -tailed) sebesar 0,01. Berdasarkan ketentuan, jika (sig.) < 0,05 maka Ha diterima. Terlihat pada data yaitu (sig.) 0,01 < 0,05, sehingga Ha diterima, artinya terdapat perbedaan peningkatan yang signifikan pada penguasaan konsep siswa antara kelas yang menerapkan model pembelajaran Advance Organizer dibandingkan kelas pembelajaran konvensional pada materi momentum dan impuls di Kelas X SMAN 1 Rumbio Jaya.

Perbedaan peningkatan rata-rata peguasaan konsep siswa kelas eksperimen lebih tinggi daripada kelas kontrol. Hasil analisis data secara deskriptif dan inferensial menunjukan bahwa penguasaan konsep siswa kelas eksperimen lebih baik dibanding kelas kontrol. Sehingga diperoleh hasil bahwa model pembelajaran advance organizer dapat meningkatkan penguasaan konsep siswa pada materi momentum dan impuls kelas X SMAN 1 Rumbio Jaya.

Kelebihan penggunaan model pembelajaran Advance Organizer ini adalah dapat meningkatkan kemampuan siswa dalam mempelajari materi baru dengan ringkasan konsepkonsep dasar tentang apa yang dipelajari dan hubungannya dengan materi yang telah ada dalam struktur kognitif siswa (pengetahuan awal). Dengan pengetahuan awal yang lebih baik akan memudahkan siswa untuk menerima serta memahami konsep-konsep pada materi yang baru. Sedangkan kelemahan yang masih dijumpai dalam penelitian ini adalah kurangnya respon yang aktif dari siswa sehingga pada saat tahap penyajian awal peneliti mengalami kesulitan dalam mengetahui konsep-konsep yang telah dimiliki oleh siswa yang nantinya akan digunakan sebagai jembatan untuk menyampaikan materi yang baru. 


\section{SIMPULAN DAN SARAN}

\section{Simpulan}

Berdasarkan hasil penelitian yang telah dilakukan didapatkan skor rata-rata penguasaan konsep siswa kelas eksperimen lebih tinggi dibandingkan kelas kontrol. Hasil analisis inferensial melalui uji-t menunjukkan perbedaan peningkatan yang signifikan pada penguasaan konsep siswa yang menerapkan model pembelajaran advance organizer dibanding siswa dengan pembelajaran konvensional, sehingga penerapan model pembelajaran Advance Organizer dapat meningkatkan penguasaan konsep siswa kelas X SMAN 1 Rumbio Jaya pada materi momentum dan impuls.

\section{Saran}

Dikomendasikan untuk penelitian lanjutan dengan memaksimalkan penerapan edvance organizer pada tahap pertama yaitu penyajian materi awal misalnya dengan memberikan sebuah video supaya siswa lebih aktif dalam merespon pertanyaan-pertanyaan yang diberikan sehingga tujuan pada tahap ini dapat tercapai yaitu mengetahui konsep-konsep awal yang telah dimiliki oleh siswa. Selain itu disarankan menerapkan model pembelajaran pada materi yang berbeda dan bidang ilmu yang berbeda guna meningkatkan mutu pendidikan dimasa yang akan datang. 


\section{DAFTAR PUSTAKA}

Ani Sulaningsih. (2014). Penerapan Model Pembelajaran Advance Organizer Menggunakan Media Peraga Molymood Gabus Untuk Meningkatkan Hasil Belajar Dan Aktivitas Siswa Kelas X2 SMAN 8 Kota Bengkulu, Skripsi tidak dipublikasikan. Universitas Bengkulu. Bengkulu.

Akinyemi Olufunminiyi Akinbobola. (2015). Enhancing Nigerian Physics Students' Attitude through the Use of Pictorial, Written and Verbal Advance Organizers. Advances in Physics Theories and Applications, Vol.40, 35-42. www.iiste.org ISSN 2224-719X (Paper) ISSN 2225-0638 (Online).

Asri Budiningsih. (2012). Belajar dan Pembelajaran. Rineka Cipta. Jakarta.

Aunurrahman. (2009). Belajar dan Pembelajaran. Alfabeta. Bandung.

Bruce Joyce. (2009). Model Of Teaching(Model-model Pengajaran). Pustaka Pelajar. Yogyakarta.

Departemen Pendidikan Nasional. (2006). Permendiknas N0.22 Tahun2006 Tentang Standarisasi Sekolah Dasar dan menengah. Depdiknas. Jakarta.

Erlina Sofiani. (2011). Pengaruh Model Inquiri Terbimbing (Guided Inquiry) Terhadap Hasil Belajar Fisika siswa pada Konsep Listrik Dinamis, Jurnal Pendidikan (2011): h.2.

Intan Putriana, Yusrizal, Adi Rahwanto. (2017). Penerapan Model Pembelajaran Advance Organizer Untuk Meningkatkan Pemahaman Konsep Dan Keterampilan Berpikir Kritis Siswa Pada Materi Fluida Dinamis di SMAN 5 Banda Aceh, Skripsi tidak dipublikasikan. Universitas Syiah Kuala. Banda Aceh.

Jahratun Mika, Zainuddin, dan Syubhan An'nur. (2014). Penerapan Model Pembelajaran Advance Organizer (AO) Untuk Meningkatkan Hasil Belajar Siswa. Jurnal Berkala Ilmiah Pendidikan Fisika 2(3): 222. FKIP Universitas Lambung Mangkurat. Banjarmasin.

Miftahul Huda. (2013). Model-model Pengajaran dan Pembelajaran. Pustaka Pelajar. Yogyakarta.

Nopriyanto. (2010). Penerapan Model Pembelajaran Advance Organizer untuk meningkatkan sikap positif siswa dalam pembelajaran matematika, Skripsi. UIN Syarif Hidayatullah. Jakarta.

Nurul Hamdanillah, Ahmad Harjono, Susilawati. (2017). Pengaruh Model Pembelajaran Advance Organizer menggunakan Video Pembelajaran Terhadap Hasil Belajar Fisika Peserta Didik Kelas XI. Jurnal pendidikan fisika dan teknologi, 3(2)119-127 (ISSN. 2407-6902).

Patta Bundu. (2006). Penilaian Keterampilan Proses Dan Sikap Ilmiah Dalam Pembelajaran Sains. Depdiknas Direktorat Jendral Pendidikan Tinggi. Jakarta.

Putri Wulan Juliana. 2015. Meningkatkan Penguasaan Konsep Dan Keterampilan Siswa Melalui Pendekatan Pakem Pada Mata Pelajaran Teknologi Mekanik, Skripsi. Universitas Sebelas Maret. Jakarta.

Sri Anita, Janet Trineke Manoy dan Suzanah. 2008. Strategi Pembelajaran Matematika. Universitas terbuka. Jakarta. 
Syaiful Bahri Djamarah. (2002). Strategi Belajar Mengajar. Rineka Cipta. Jakarta.

Tasiwan, S.E. Nugroho, Hartono. (2014). Pengaruh Advance Organizer Berbasis Proyek Terhadap Kemampuan Analisis - Sintesis Siswa. Jurnal Pendidikan Fisika Indonesia 10 (2014) 1-8, DOI: 10.15294/jpfi.v10i1.3044.

Wayan Nurkancana dan Sunartana. 2003. Evaluasi Hasil Belajar. Usaha Nasional. Surabaya. Wina Sanjaya. 2008. Perencanaan dan Desain Sistem Pembelajaran. Kencana. Jakarta. 